\title{
Logos and Pallaksch. The Loss of Madness and the Survival of Poetry in Paul Celan's "Tübingen, Jänner"
}

Silke-Maria Weineck, University of Michigan, Ann Arbor, U.S.A.

For Marc L.

\begin{abstract}
This paper argues that Celan's Hölderlin poem Tübingen, Jänner is a critical poetic exploration of the concept of poetic madness associated with Hölderlin's life and work. I attempt to demonstrate that the poem moves between two poles, logos/techne/reflexion and madness i.e. the "pallaksch" recorded as Hölderlin's mad "unword." While poetry itself seems to collapse under the pressure of "this time," it also reasserts itself as the medium that recovers speaking, that moves, however tentatively, to reunite the solitary words of mad unlanguage to the fragile structure of poetic speech - a process during which poetry disintegrates into mad babble at the same time as it turns this mad babble back into poetry. This reading introduces a kaddish into the pallaksch, mourning, not last of all, the fragmentation of mourning itself, its parenthetical character, its decomposition from ritual high speech into incomprehensible prattle. The brackets around the double "pallaksch" at the end both protect and isolate mad language from its poetic frame - at the end, madness remains part of poetry, but poetic writing must contain it in the very act of citing it as one of its grounds.
\end{abstract}

Writing about poetic madness always is a project of demystification and remystification. It is demystification because it tries to comprehend and formalize precisely that which presents itself as resisting understanding; any attempt to define madness loses the essence of its elusive power and appeal. Madness demystified is not madness anymore - it becomes either strategy or disease. Talking about madness, then, at the same time necessitates remystification, the creation of a space for madness apart from its critique, an elsewhere that always runs risk to be only emptiness, mere negation without force. 
The history of poetics abounds with theories of poetic madness and their modifications and refutations; in fact, it would not be too much of an exaggeration to say that this movement is the history of poetics, since it constitutes, from Plato on, the privileged inquiry into the quintessential difference between poetry and all other modes of speaking and writing. This article will trace the movement of de- and remystification in Celan's poem, Tübingen, Jänner, a poem retelling the tales of madness that surround Hölderlin.

Since Hölderlin is not merely a poet, but a legendary figure, legendary as the quintessential mad philosopher poet, any poetic encounter with him is an encounter with the myth, or perhaps the reality, of poetic madness. Celan's poem is unmistakably a poem that speaks of Hölderlin as well as of his madness; I will argue that it does more: it speaks of the danger of this specific legend, of the veil it draws over Hölderlin's words. It is a meditation both on madness and on a specific gaze on madness, a poem on reading and blindness, and, lastly, not on the power of madness over poetry, but of poetry over madness.

Tübingen, Jänner

Zur Blindheit überredete Augen.

Ihre - 'ein Rätsel ist Reinentsprungenes' -, ihre

Erinnerung an schwimmende Hölderlintürme, Mövenumschwirrt.

Besuche ertrunkener Schreiner bei diesen tauchenden Worten:

Käme,

käme ein Mensch, käme ein Mensch zur Welt, heute, mit dem Lichtbart der Patriarchen: er dürfte, spräche er von dieser Zeit, er dürfte nur lallen und lallen, immer-, immer-

zuzu. 
The references to Hölderlin are clear: the poem mentions the name, the late Hölderlin's home in Tübingen, the carpenter, and the tower; it quotes from the Hölderlin hymn Der Rhein, and it closes with mad Hölderlin's sunken word: "Pallaksch" - or almost closes, for its last mark is a closing bracket. It is also, with equal force, a poem touching on madness. Its imagery is hallucinatory swimming towers, visits of drowned carpenters, lightbeards. It is inhabited by voices and figures - by many more voices and shapes than appear on its surface, as the many excellent readings of this poem have shown. It moves from what has been conveniently called "hermetic" imagery towards stuttering, stammering, and babble. It quotes, as I will explain, two mad words, "immerzu" and "pallaksch." Without doubt, madness is its most clearly drawn frame of reference, but it is not one single madness that is at stake here.

If a human came - and the "if" implicit in the German subjunctive is repeated three times -, if a human came, and if he were of a certain quality, a quality associated with enlightened, prophetic, potentially biblical speech, with the "light beard of the patriarchs" - he would not be able, or allowed, to speak at all, he "might only babble." Perpetually: "immer-, immer-/zuzu." Here, the babbling, the lallen, already invades the poem. The "perpetually" of immerzu falls apart, into "immer-, immer-" and "zuzu." A babbled word, a nonword. Also, in the repetition of "zu," a doubling of closure - for "zu" means "shut" - and, at the same time, a negation of closure - for "zu" also means "towards." It is this simultaneity of opening and closing that strikes me as most significant in this poem's advance towards the madness implicit in its last word, pallaksch. The "immerzu" already is a mad word, and, like "pallaksch," a quotation, although, unlike "pallaksch," a silent one. It stems from Georg Büchner's play Woyzeck, and Celan, in his Büchner-Preisrede, refers to "immerzu" as Woyzeck's "Wahnsinnswort" ("word of madness"). Woyzeck is haunted by it while he contemplates the murder of his fiancée Marie. ${ }^{3}$ Woyzeck's hallucination itself is, again, a quotation: he overheard it when Marie cheered on her dance partner, "immer zu, immer zu," - "faster," "don't stop," "go on, go on!"

Thus, "immerzu" enters Celan's poem doubly mutated, as a memory of a memory, an allusion to an allusion, changing from innocuous flirtation to a murderous urge to the perpetuity of a broken language. In drawing Woyzeck's Wahnsinnswort into the poem, Celan does not only strengthen the poem's movement towards madness, he also obliquely refers to his famous Preisrede that centres on poetry's movement towards silence. ${ }^{4}$ 
Rainer Zwibowski justly calls the poem "diaphanous." It is not only the title that layers meaning over meaning; a comparable exegesis could probably be given for every single line. There is a multiple memory written into this poem, memories of madnesses of radically different kinds. This condensation of various historical references could itself be read as a mad loss of location, a temporal disorientation, a loss of associative control. On the other hand, multiple evocation is, of course, a poetic prerogative, not mad by itself, and while the ancient association of poetry and madness may be partially grounded precisely in such parallel discursive practices, the multiple disorientations of Celans poem, for me, evoke an imposing poetic control rather than its loss. This poetic control in the face of madness, the power of Rede, is, indeed, central to the poem.

"Immer-, immer-/zuzu." Towards what does the stammering language move? The next line after "zuzu" is blank (and the blankness of verse-breaks is never accidental in Celan's poetry, never a mere convention). Towards silence, then? An openness towards nothingness? Not quite, for there is a remainder, even though this remainder of speech is triply qualified: "pallaksch" is not only a non-word, it is also not the poem's word, but a quote from one who stopped speaking, from after poetry; it is doubled; lastly, the madman's quoted nonword appears in brackets.

The pallaksch, as it appears in Tübingen, Jänner, repeats the gesture of opening and closing on another level. For while it does not mean anything, by itself, the nonword pallaksch which invades poetry (as madness, perhaps, invaded Hölderlin's poetic life) is also something of a biographical watchword, signalling to Hölderlin readers that it is the late, the mad Hölderlin who is at stake here, the Hölderlin who, as his friend Schwab reported, refused to distinguish between "yes" and "no."

In perhaps the most controversial single line of criticism in this century, Theodor W. Adorno asserted that "to write poetry after Auschwitz is barbarious." Adorno is said to have reconsidered this line after he became familiar with Celan's work; however, he did not take it back. And perhaps this line is most appropriate precisely in reading Celan, and especially this poem, for the barbarians, originally, are those who stammer or babble, who do not speak the language, foreigners: to speak of this time, Celan, perhaps in a deeper agreement with Adorno, is to stammer and babble, barbariously.

Hölderlin is said to have retreated into "pallaksch" with signs of great distress, under conversational pressure by those who wanted to visit the fam- 
ous madman and take a memory home, some meaning, some enlightenment. After all, Hölderlin himself had been, or become, something of a poetic patriarch; he did compose the Vaterländische Gesänge, patriotic (patriarchal?) songs. Confronted with later expectations to live up to this role of national treasure, however, he apparently did not have much to say after a certain point: "pallaksch." At Celan's time, "this time," one might have remembered different quotations from Hölderlin, and, more importantly, different quoters. He was, after all, a very popular poet with the Nationalsocialist propaganda machine. So it might have been necessary to answer to those other quotations with a total refusal of anything that could possibly be constructed as patriotic rhetoric in the service of nationalist sentiment: "pallaksch" is always a refusal when meaning of this sort is requested, or, for that matter, any meaning in any ideological service.

Having established this context, as I think remains necessary in any encounter with Paul Celan, I will abandon it again, for this is not an article on Celan, on Germany, or on "this time," but on poetry and madness, on the movement between logos and pallaksch, and Tübingen, Jänner, speaks on this as well. It speaks, I insist, in the very act of asking profound questions about the possibility of speaking, of insight, of remembrance. It does not say that no one may speak anymore, only that certain humans could not speak of this time in a certain way: that no patriarchal pronouncements are possible "today," and, by extension, that none may be expected here, in the space of this poem. At the same time, it is important to keep in mind that the patriarchs themselves have, at times, privileged babble over logos. Syntactically and phonologically, Celan's poem at the end operates in striking parallelism to a passage in Isaiah: "Jawohl, Gott wird einmal mit unverständlicher Sprache und mit einer fremden Zunge reden zu diesem Volk, er, der zu ihnen gesagt hat: 'Das ist die Ruhe: schaffet Ruhe den Müden, und das ist die Erquickung!' Aber sie wollten nicht hören. Darum soll so auch des Herrn Wort an sie ergehen: 'Zawlazaw zawlazaw, kawlakaw kawlakaw [...]' (Isaiah 28, 11-12)." Certainly, "(pallaksch. pallaksch.)" surely does not speak of God's presence-to-come. In speaking of Hölderlin, it is always a matter of God's absence, an absence that could hardly be more final than in these words.

While Tübingen, Jänner, refuses patriarchal speech of a single and familiar tongue, then, it places no prohibitions on speaking in a foreign one, even though it is not the strangeness of God that makes its language so alien. It is still possible to quote the mad Hölderlin who, even though only in parenth- 
esis and after poetry has broken down, has started to stammer. The pallaksch appears as an intensification of stammering, an even more dramatic loss of language than the "immer-, immer-/zuzu," a final abandonment of the poem's own voice (if there still is, at this point, something like the poem's "own" voice). At the same time, however, the "pallaksch" does not speak of the abandonment of speech alone. While moving from mad imagery to the mad word to the non-word, the poem, in a parallel move, recuperates meaning while abandoning it on the surface. Almost unnoticeably, the "pallaksch" is reinvested with significance by the poem that quotes it, only seemingly negating itself through this act: pallaksch picks up fragments of the preceding line, in a condensation of "Patriarchen," "lallen," and a final sound, "ksch," which might be a code for "kaddish," the ritual prayer of mourning, a cryptic reference to the biblical patriarchs, perhaps, who may not speak anymore, not even to say kaddish. Or it is the sound one makes to chase away the birds whirring around the tower: "ksch!" In this light, "pallaksch" figures as an open invitation to read, once again, after the silence of the blank line, after speech has been restricted to babbling, after Hölderlin has stopped to write the poetry that made him famous. Thus, while poetry itself seems to collapse under the pressure of "this time," it also reasserts itself as the medium that recovers speaking, that moves, however tentatively, to reunite the solitary words of mad unlanguage to the fragile structure of poetic speech - a process during which poetry disintegrates into mad babble at the same time as it turns this mad babble back into poetry.

I like the interpretation that reads the kaddish into the pallaksch. Certainly many things still need to be mourned, including the fragmentation of mourning itself, its parenthetical character, its decomposition from ritual high speech into incomprehensible prattle. What does it mean, however, to use the mad word - if it is indeed used in this way - in order to say/not say kaddish? What does it mean, in a broader sense, to take the mad word and make it mean? Like no poet before him, Celan has struggled to simultaneously preserve and erase meaning, to let poetry speak and to protect it from easy grasp. The great seriousness of this effort perhaps also makes his poetry most suited to touch on madness, for, as Foucault has argued powerfully, the mad as well may need to have their voice both heard and sheltered. Celan, if anyone, can perhaps teach us how to speak of or for the mad without being one of their "best spokesmen" of whom Derrida says that they are the ones who "betray them best." 5 
If Tübingen, Jänner, has anything to say on poetic madness, then not on that sort of madness that is closer to inspiration, a benign interference of an abundance of meaning that, while it cannot be demanded, also does not demand anything back from the poet. It is not Plato's theia mania, ${ }^{6}$ not even Hölderlin's "insane quest for a consciousness."7 "Pallaksch" is, to repeat, first and foremost a refusal, a refusal even of itself: a madness that cannot be read, understood, criticized, integrated into a work, or deconstructed. ${ }^{8}$ It refuses itself to the logos. The madness of "pallaksch," is, in want of a better word, real and final: before it enters Celan's poem, that is. For if we want to continue speaking, then it serves no purpose to simply repeat the "pallaksch." The "words without language" that constitute radical madness are not readily available to either poets or critics, on logical as well as on ethical grounds. As even the most obscure (and I do not use this term in a derogatory sense) works of modernism and postmodernism show, to speak as poet or as critic is to produce meaning, however polyvalent, instable, obstructed, or "hermetic" a meaning it may turn out to be. Not only "philosophy ... always lives by emprisoning madness"9 - so does poetry, ultimately. Tübingen, Jänner - and this reveals how sensitive a poem it is -- marks this imprisonment by the brackets that encircle the "pallaksch," anticipated, perhaps, by the allusion to the seagulls that encircle Hölderlin's tower (as children, we have all drawn seagulls like a pair of round brackets in the air).

Tübingen, Jänner is a difficult poem, perhaps even more complex than Celan's poems of this period are in general. It would take great patience to read it fully, to follow all its twists and implications, and I will not attempt to do that here. What can be said, however, is that it is itself a poem about attentive reading, about the great effort of attention that it takes to read madness - not the high madness of the patriarchal prophets, but the madness of a raving maniac who had been a great poet.

Tübingen, Jänner is written in a mode of multiple disorientation, in figures of reflection and inversion: the tower swims, the carpenter who has drowned pays a visit to words that dive into blankness; vision is voided by speech, but speaking is only allowed as babbling. Only part of these tropes can be retranslated into a conventional image: ${ }^{10}$ standing at the railing of the tower, looking down at the Neckar, seeing the tower's and the seagulls' reflection in the water, frozen water perhaps, because it is January - but even if this accessible image is there, in these lines, it is there 
only as a remembrance of an image, remembered by eyes blinded by speech: "über-redet," persuaded into blindness, a vision superceded by too much talking. What words can persuade eyes to go blind, not to see? The same diving words which the carpenter is visiting? The poem announces "these diving words:" but what follows is, again, a blank line. So perhaps it is rather the words that invade the memory of the image: "ihre-'ein Rätsel ist Rein-/entsprungenes'-ihre/Erinnerung."

"Ein Rätsel ist Reinentsprungenes," without a line break, is the first line of the fourth stanza of Hölderlin's Der Rhein. This quotation functions as an oblique clue, for Der Rhein, too, will later speak about a blinding by words, in the context of Rousseau's divine madness:

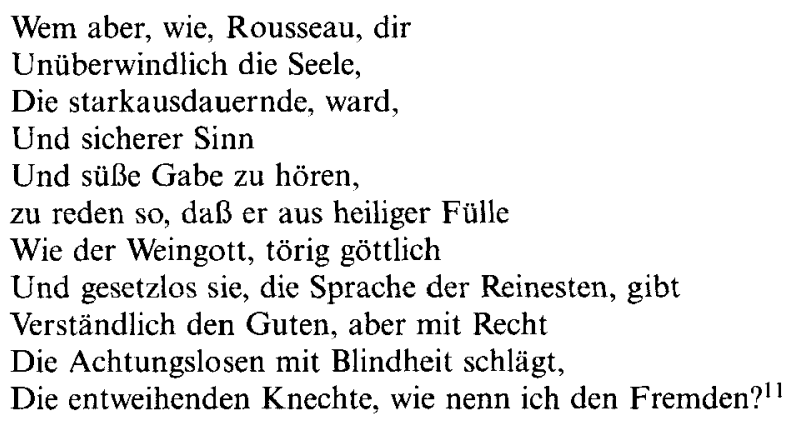

It is virtually impossible to render a syntactically or rhythmically equivalent translation in English. Here is an attempt at a fairly close prose translation, which, strange as it may sound, does not sound nearly as strange as the original: "But to whom, like to you, Rousseau, the soul became invincible, the strongly enduring one, and to whom was given secure sense and the sweet gift to hear, to speak, so that he gives, from sacred abundance, like the wine god, foolishly divine and lawlessly this, the speech of the purest, intelligible to the good ones, but rightly striking with blindness the inattentive ones, the desecrating serfs - how do I name the stranger?"

Clearly, Celan's image of "eyes per-/suaded to blindness" alludes to this passage in Hölderlin's Rhein - the direct quotation ("ein Rätsel...") already points us to the hymn, and the image of a blindness by Rede is so extravagant that the connection appears hard to miss. And yet, as far as I know, none of this poem's readers has picked it up. ${ }^{12}$ The oblique presence of Hölderlin's Rousseau stanza, however, lends ambiguity to the blindness of Celan's opening lines, throwing doubt on all the readings that identify the blind eyes with 
the poem's voice. ${ }^{13}$ Reading Celan with Hölderlin, however, suggests that it is not necessarily the poet's or the poem's eyes that have gone blind. It is rather a blindness of inattention, the blindness of those who are ill-disposed to hear and to recognize the language of the purest - Hölderlin's language, for instance, including his "pallaksch."

The blind eyes are the subject of memory, but of a hallucinatory memory invaded by a Hölderlin fragment. The blind eyes, gazing inward rather than paying attention, see nothing but the reflection of a legend - the mad poet in the tower, the carpenter made caretaker. They may only think that they remember Hölderlin. In a departure from the usual reverential exegesis directed at them, the first two stanzas' disorienting imagery may perhaps be read as a parody on the culture tourists who pay madness a visit, who remember a famous line, "ein Rätsel ist Reinentsprungenes," or, even more vaguely, the most famous Hölderlin poem, "Hälfte des Lebens." The first stanza of that reads:

\author{
Mit gelben Birnen hänget \\ Und voll mit wilden Rosen \\ Das Land in den See, \\ Ihr holden Schwäne, \\ Und trunken von Küssen \\ Tunkt ihr das Haupt \\ Ins heilignüchterne Wasser. ${ }^{14}$
}

Debris of this poem pervades the first stanzas of Tübingen, Jänner. The "trunken" swans turn into "ertrunkene" Schreiner, the diving heads of the swans become the diving words, diving away, perhaps, from the inattentive gaze. While Celan's opening stanzas, at first glance, appear to create a mad imagery, they might also just play with this expectation of exotic insaneries that the name Hölderlin evokes. Poetry and the legend of the mad poet merge into a jumble of Hölderlin fragments, Tübinger allusions, mythical inventions like the one of a drowned carpenter and Romantic stock images. What appears, at first glance, as a poem on madness, might indeed be the opposite: a poem on the blind gaze of reason inhabited by the language of dead patriarchs that no longer means anything. ${ }^{15}$ The drowned carpenter, perhaps, is the carpenter Plato who build the three beds, the ideal, the real, and the mimetic one. This is not as far-fetched a reading as it might seem. The "ein Mensch" of the Celan poem may well be another unmarked Hölderlin quotation, again from Der Rhein. There, Hölderlin speaks of Socrates in the 
following words: "bis in den Tod/Kann aber ein Mensch auch/Im Gedächtnis doch das Beste behalten" ("into death/however, a man, too, can/remember what is best.")

The remembrance of Tübingen, Jänner, however, is hardly a remembrance of what is best, and it is certainly not one that springs forth purely. On the contrary, Tübingen, Jänner, is a masterful arrangement of contaminations, a different form of stammering, a reflection on the impossibility of committing purity to language. Inattentive readers are struck by blindness "rightly," Hölderlin insists, and Celan, perhaps, with him - for inattentiveness is already a form of blindness. In talking of this blindness to and by words, Celan recreates its condition with his own language that shields Hölderlin, the poet and the madman alike, from an understanding that would come all too quickly.

Tübingen, Jänner moves two Hölderlin quotations into play: "ein Rätsel ist Reinentsprungenes," and "pallaksch." 16 The distance between the two seems unbridgeable. And yet, they occur within the same poetic space, once in parentheses, once in brackets: tokens of their separateness from the blindness of inattentiveness. Both the riddle of pure origin and the quite different mystery of Hölderlin's madness are set apart, and thus also linked. Both quotations are subtly altered: the "pallaksch" is doubled, the pure origin is cut apart by a line break: "ein Rätsel ist Rein-/entsprungenes." This emphasizes the jump implicit in "ent-sprung-en," the unexplicable suddenness of origin. It also, however, creates a different emphasis, away from purity, towards "entsprungen." And "entsprungen," taken by itself, does not only mean originated, it also means escape, quite specifically in the sense of an escape from jail or from an asylum. The Schöffler-Weis dictionary of German and English actually lists "(ausbrechen) escape (aus from); (Gefängnis) to break out (of prison)" as the primary meaning of "entspringen." 17 Celan thus points us to the mystery of escape, of breaking free, of being lawless, perhaps, like the wine-god, foolishly, or madly, divine. For madness, especially a madness like Hölderlin's, remains a riddle. An escape, a pure escape: breaking out, springing forth, enigmatically, irrevocably. Celan's enjambement, however, suggests that it is not an escape into purity, but the opposite: "rein-/entsprungen," escaped from purity, for the only purity there could possibly be is silence. It is silence towards which Celan's poetry is drawn most strongly, and it is silence which it resists at all times. The poet Jacques Dupin has formulated this conflict most succinctly in his eulogy on Paul Celan: "He cannot stop speaking, for otherwise the silence would end." 18 
The only purity there could possibly be is silence, I have said, for Celan's poetry as a whole, not just Tübingen, Jänner, shows how inescapably language has been contaminated. There is, of course, another way besides silence that leads out of this contamination, a way Celan has used frequently: neologism, "words without language," leading back to "pallaksch." Hölderlin's nonword may indeed be read as a word of radical purity if we want to understand purity as pure identity. If Schwab was correct, then "pallaksch," and Celan could read this in Hellingrath's Hölderlin edition, can be understood as the ultimate negation of the double bind of identity as difference:

one could take it to mean once yes, once no, but usually he meant nothing at all by it, but used it when his patience or the remains of his concentration were exhausted and he did not want to go to the trouble of thinking whether he were to say yes or no. ${ }^{19}$

We might transcribe the last line, then, simultaneously, as: ("Yes. Yes."); ("Yes. No."); ("No. No."); ("Nothing at all. Yes.") ("No. Nothing at all.") - etc. The "pallaksch," then, can indeed stand as a cipher for "pure origin" if we want, in the metaphysical tradition, understand "origin" as a radical state of identity preceding any differentiation. But, Tübingen, Jänner seems to suggest, this would, indeed, mean "nothing at all," nothing at all. And while the poem moves towards this nothingness, it also brackets it; while it reserves the privilege of the last line for this nothing at all, it also, ever so cautiously, writes a whole history into it: patriarchs, their babble, and, perhaps, a kaddish. Origin and history become undistinguishable, and so do madness and purity: however, this is not to say that they are the same, only that the oscillation between them is too rapid to allow for their distinction.

To conclude in a different voice: no etiology, be it philosophical, aesthetic, psychoanalytic, sociological, or biochemical, has fully accounted for this phenomenon, the poet who goes mad or the madman who writes poetry even though all these disciplines can, of course, put forth interesting and illuminating hypotheses. To say that poetic madness cannot be accounted for, however, does not mean that it is dismissable as an idea. The mad poet is a legendary figure older than our historical records allow us to safely know, and to disregard his persistent presence as just another myth to be demystified would be merely another form of inattentiveness. Certainly, poetry and madness are not linked by any necessity that could be firmly established: there have been enough great poets that were, to all appearances, perfectly sane, 
and more madmen that have, to all appearances, never written any poetry. So it is surely tempting to declare the notion of poetic madness obsolete, too nebulous, too multifarious, too heavily burdened by folklore, religion, ideology, history. And yet, I know of no other word than madness that will serve us to perceive Hölderlin's pallaksch, and I know of no other means but poetry to rescue it, however tentatively and cryptically, for the continuous miracle of meaning that is at stake "in this time."

\section{REFERENCES}

1. To blindness per-/suaded eyes./Their - "a mystery is what purely/springs forth" -, their/remembrance of/swimming Hölderlin towers, seagull-/circumwhirred.//Visits of drowned carpenters to/those/diving words://If there came,/if there came a man,/if there came a man to the world, today, with/the lightbeard of the/patriarchs: he might,/if he spoke of this/time, he/might/only babble and babble,/ever-, ever-/moremore.//("Pallaksch. Pallaksch."). This translation is mine, and since it is not meant to "translate" in any deeper sense, but only to give an approximation, I will not repeat here everything that has been said about the impossibility of translating poetry, or Celan's poetry.

2. Christoph Theodor Schwab, a friend and frequent visitor of Hölderlin, calls "pallaksch" Hölderlin's "favourite expression" ("Lieblingsausdruck"). Hölderlin. Sämtliche Werke, Historisch-Kritische Ausgabe, Norbert v. Hellingrath and Friedrich Seebass und Ludwig v. Pigenot (Eds.) München/Leipzig: 1913-23, Bd. VI, 444. Cf, the end of this article.

3. "Soll ich? Muß ich? Hör ich's da auch, sagt's der Wind auch? Hör ich's immer, immer zu, stich tot, tot." (Should I? Must I? Do I hear it there, too, does the wind say it, too? Hear it always, always, on, on, stick dead, dead.") Georg Büchner, Gesammelte Werke, Gerhard P. Knapp (Ed.), Goldman: n.p., 1970, 175.

4. In that speech, the Meridian, Celan also comments on Büchner's short story Lenz that describes the descent of the poet Lenz into madness; the first sentence of the story reads, "Am 20. Januar ging Lenz ins Gebirg." The January of the poem's title refers itself back to this madness as well, then. January 20th, however, is also the date of the Wannsee-conference. The "Jänner" of Tübingen, Jänner, emerges as the splintered time of multiple memory. For further speculations on the role of "January," cf. Rainer Zbikowski, "schwimmende Hölderlintürme": Paul Celans Gedicht "Tübingen, Jänner - diaphan," in: Der glühende Leertext: Annäherungen an Paul Celans Dichtung, Otto Pöggeler and Christoph Jamme (Eds.), München: Fink, 1993, 185-211.

5. Jacques Derrida, "Cogito and the History of Madness," in: Writing and Difference, trans. Alan Bass, Chicago: University of Chicago Press, 1978, 31-63.

6. Cf. especially Phaedrus and Ion.

7. ...das geisteskranke Fragen nach einem Bewußtsein...”; Friedrich Hölderlin, Anmerkungen zum Ödipus, Sämtliche Werke (Frankfurter Ausgabe), historisch- 
kritische Ausgabe, hg. Friedrich Sattler, Frankfurt/M: Stroemfeld/Roter Stern, 1988, Bd. 16, 247-258: 255.

8. Thanks to Arkady Plotnitsky for his gift of a definition of madness as "that which cannot be deconstructed."

9. Derrida, Cogito, 61.

10. Peter Szondi has very cogently and sensitively written on the need to also attempt to recognize and retrieve these conventional, as it were prepoetic images from Celan's poetry. Cf. Celan-Studien, Frankfurt: Suhrkamp, 1967.

11. Friedrich Hölderlin. Werke, Briefe, Dokumente. Nach der Kleinen Stuttgarter Hölderlin-Ausgabe, hg. von Friedrich Beißner. Ausgewählt und mit Nachwort von Pierre Bertaux. München: Winkler, 1963, 150-154: 153.

12. For other readings about or touching on Tübingen, Jänner, cf. Bernhard Böschenstein, Hölderlin and Celan, Hölderlin-Jahrbuch 1982-83, 147-155; B. Böschenstein, “Tübingen, Jänner," in: Über Paul Celan, Dietling Meinecke (Ed.), Frankfurt: Suhrkamp, 1973, 101-112; Sigrid Bogumil, Celans Wende, Entwicklungslinien in der Lyrik Paul Celans I. Neue Rundschau H. 4 (1982): 81-110; S. Bogumil, "Celans Hölderlinlektüre im Gegenlicht des schlichten Wrotes," in: CelanJahrbuch 1, Hans-Michael Speier (Ed.), Heidelberg. Carl Winter, 1987, 81-125; Philippe Lacoue-Labarthe, La poésie comme expérience, Paris: Christian Bourgois, 1986; Rainer Zbikowski, "Schwimmende Hölderlintürme:" Paul Celans Gedicht "Tübingen, Jänner" - diaphan, in: "Der glühende Leertext:" Annäherungen an Paul Celans Dichtung, Otto Pöggeler and Christoph Jamme (Eds.) 185-211.

13. In Hölderlin and Celan (op.cit.), Bernhard Böschenstein suggests, without further explanation, that the blind eyes parallel the poet's diving words. In Tübingen, Jänner (op.cit., 101), Böschenstein suggests that the "eyes have let themselves be convinced (überzeugen) that blindness is proper to them" - ignoring the strong distinction between "überreden" (persuade) and "überzeugen" (convince), where only the latter connotates conviction. Other readings offer only slight modifications of this view, and none explain sufficiently whose Rede has caused the blindness.

14. "With yellow pears, and ample with wild roses, the land hangs into the lake, you comely Swans, and drunken with kisses you dunk your heads into sacredly sober water."

15. In light of the multiple allusions set free by Der Rhein, we might have to count Rousseau, too, amongst the possible patriarchs with the beards of light. Hölderlin, at least, seems to attribute to him the mad language of "the purest ones," a line echoing with the enigma of pure origin. The potentially blinding language of the purest philosopher poet, we might spin this reading further, must turn into babble as well; enlightenment, the rhetoric of freedom and progress, must turn (or has turned) into babble in "this time." The mad language of purity, prophecy, divinity, the most ancient mode of elevated speech, is dead.

16. It is always possible to read "pallaksch," in this poem, not only as modern patriarchs' mournful babble, borrowed from a not-anymore-poet, but also as a laconic, ironic play on "platsch," the onomatopoetic German term used to imitate the sound of something hitting the water, destroying reflection. It is possible, but not, I think, very illuminating in the end.

17. Schöffler-Weis, Taschenwörterbuch, Deutsch-English, Stuttgart. Klett, 1965, 266, col. 1. 
18. Quoted after Sigrid Bogumil, Celans Hölderlinlektüre im Gegenlicht des schlichten Wrotes, op.cit. 93.

19. Hölderlin, Sämtliche Werke, op. cit., Bd. VI, 444.

Silke-Maria Weineck. Born 1963. PhD. University of Pennsylvania. Assistant Professor, German Languages and Literature, University of Michigan, Ann Arbor. Has published articles on poetic madness in Plato's Ion and in Shelley's Julian and Maddalo. 